\title{
Clinical investigation of oral findings in inherited disorders of platelet function
}

\section{Herediter trombosit fonksiyon bozukluğu olan hastalarda görülen oral bulgularinin klinik olarak incelenmesi}

\author{
Müjgan Güngör Hatipoğlu1, Özden Kansu², Yahya Büyükaşık³ \\ 'Department of Oral Diagnosis and Radiology, Dental Clinic, Dumlupinar University, Research and Training \\ Hospital, Kütahya, Turkey \\ ${ }^{2}$ Department of Oral Diagnosis and Radiology, Faculty of Dentistry, Hacettepe University, Ankara, Turkey \\ ${ }^{3}$ Department of Hematology, Faculty of Medicine, Hacettepe University, Ankara, Turkey
}

\begin{abstract}
Objective: Bleeding disorders are a very important health problem due to the associated high risk of hemorrhage during dental procedures. The present study aimed to investigate oral manifestations of inherited disorders of platelet function (IDPF).

Materials and Methods: The study included 20 IDPF patients (mean age: $31.90 \pm 10.71$ years) and 40 healthy controls (mean age: $31.63 \pm 9.07$ years). Tooth brushing habits, level of education, and clinical index scores (Simplified Oral Hygiene Index [OHI-S], Decayed Missing Filled Teeth Index [DMFT] index, probing depth [PD] index, Gingival Bleeding Index [GBI], and Community Periodontal Index [CPI]) were recorded.

Results: There weren't any significant differences between the 2 groups with respect to tooth brushing habit, level of education level, OHI-S, DMFT index, or CPI ( $>0.05)$, whereas significant differences in PD index and GBI were observed between the groups $(p<0.05)$.

Conclusion: The present study's findings show that IDPF has a negative effect on periodontal tissues. (Turk J Hematol 2011; 28: 294-8)

Key words: Blood platelet disorders, thrombocytopathy, gingival hemorrhage, periodontal diseases, oral hygiene, dental caries

Received: March 3, 2009

Accepted: April 30, 2010

Özet

Amaç: Diş hekimliğinde uygulanan işlemler sırasında kanama, kanama problemi olan hastalarda oldukça önemlidir. Bu çalışmada Herediter Trombosit Fonksiyon Bozukluğu (HTFB) olan hastaların ağız bulguları değerlendirilmiştir.
\end{abstract}

Address for Correspondence: Assist. Prof. Müjgan Güngör Hatipoğlu, Department of Oral Diagnosis and Radiology, Dental Clinic, Dumlupinar University, Research and Training Hospital, 43270 Kütahya, Turkey Phone: +90 2742652031 Fax: +90 2742652277 E-mail: mujgan121@yahoo.com 


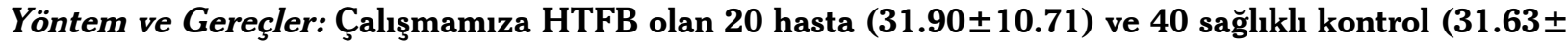
9.07) alınmıştır. Diş fırçalama alışkanlıkları, eğitim seviyeleri ve klinik indeksler; Modifiye Oral Hijyen Indeksi (OHI-S), Çürük indeksi (DMF-T), cep derinliği (PD), diş eti kanama indeksi (GBI) ve Genel Periodantal indeks (CPI) kaydedildi.

Bulgular: Gruplar arasında, diş fırçalama alışkanlıkları, eğitim seviyesi, OHI-S, DMF-T ve CPI sonuçları için istatistiksel olarak anlamlı bir farklılı bulunmadı ( $>0.05)$. PD, GBI sonuçları ise iki grup arasında istatistiksel olarak anlamlı bulundu $(\mathrm{p}<0.05)$.

Sonuç: Bu çalışmada HTFB'nin periodontal dokuları etkilediği görülmüştür.

(Turk J Hematol 2011; 28: 294-8)

Anahtar kelimeler: Trombosit hastalıkları, trombositopatiler, dişeti kanaması, periodontal hastalık, oral hijyen, diş çürükleri

\section{Introduction}

Platelet function disorders are uncommon causes of bleeding disorders treated by hematologists. Inherited disorders of platelet function (IDPF) are diverse and include defects in platelet adhesion, aggregation, secretion, and platelet procoagulant activity. Clarification of the abnormal platelet mechanism in such patients has provided invaluable insights concerning the key aspects of platelet physiology and hemostasis. IDPF patients at all times must be made aware of the importance of oral health. Based on anatomical location, bleeding in the oral cavity can be life threatening. The frequency of oral findings in IDPF patients is not precisely known; however, oral bleeding in related diseases can occur in $\leq 70 \%$ of patients [1-7].

\section{Materials and Methods}

The present study included patients that were referred to the Department of Oral Diagnosis and Radiology by our hospital's hematology department. The Hacettepe University Ethics Committee approved the study protocol and written informed consent was obtained from each participant. In all, 20 IDPF patients and 40 healthy controls were included in the study. The 20 patients (5 male and 15 female) had a mean age of $31.90 \pm 10.71$ years (range: 19-52 years) and were diagnosed with IDPF (Table 1). The control group consisted of 40 systemically healthy age- and gender-matched individuals (10 male and 30 female) with a mean age of $31.63 \pm 9.07$ years (range: $18-51$ years) that presented to our clinics for routine care.
All the participants were examined while in the supine position in a dental chair under standard lighting conditions. Data collected via clinical oral examinations included the Simplified Oral Hygiene Index (OHI-S), Decayed Missing Filled Teeth (DMFT) index, Probing Depth (PD) index, and Gingival Bleeding Index (GBI) [8-11]. Periodontal status was evaluated using the Community Periodontal Index (CPI) [12]. These indexes were used to identify periodontal disease, dental caries activity, and oral hygiene status. One dentist performed all clinical oral examinations.

Table 1. Distribution of IDPF Patients

\begin{tabular}{llcc}
\hline & Disease & Age (years) & Gender \\
\hline 1 & von Willebrand Disease & 31 & $\mathrm{~F}$ \\
\hline 2 & Hermansky-Pudlak Syndrome & 25 & $\mathrm{M}$ \\
\hline 3 & von Willebrand Disease & 50 & $\mathrm{M}$ \\
\hline 4 & Platelet-release reaction defects & 25 & $\mathrm{~F}$ \\
\hline 5 & Hermansky-Pudlak Syndrome & 29 & $\mathrm{M}$ \\
\hline 6 & von Willebrand Disease & 54 & $\mathrm{M}$ \\
\hline 7 & von Willebrand Disease & 22 & $\mathrm{~F}$ \\
\hline 8 & Grey Platelet Syndrome & 23 & $\mathrm{~F}$ \\
\hline 9 & Grey Platelet Syndrome & 28 & $\mathrm{~F}$ \\
\hline 10 & von Willebrand Disease & 34 & $\mathrm{~F}$ \\
\hline 11 & von Willebrand Disease & 22 & $\mathrm{~F}$ \\
\hline 12 & von Willebrand Disease & 38 & $\mathrm{~F}$ \\
\hline 13 & Platelet-release reaction defects & 22 & $\mathrm{~F}$ \\
\hline 14 & von Willebrand Disease & 43 & $\mathrm{~F}$ \\
\hline 15 & Platelet-release reaction defects & 37 & $\mathrm{~F}$ \\
\hline 16 & Platelet-release reaction defects & 32 & $\mathrm{~F}$ \\
\hline 17 & Glanzmann Thrombasthenia & 46 & $\mathrm{~F}$ \\
\hline 18 & von Willebrand Disease & 21 & $\mathrm{M}$ \\
\hline 19 & Hermansky-Pudlak Syndrome & 47 & $\mathrm{~F}$ \\
\hline 20 & von Willebrand Disease & 45 & $\mathrm{~F}$ \\
\hline & & & \\
\hline
\end{tabular}


Table 2. Tooth Brushing Habits and Level of Education

\begin{tabular}{lcccc}
\hline $\begin{array}{l}\text { Tooth Brushing } \\
\text { Habit }\end{array}$ & $\begin{array}{c}\text { Elementary School } \\
\text { n }\end{array}$ & $\begin{array}{c}\text { High School } \\
\text { n }\end{array}$ & $\begin{array}{c}\text { University } \\
\text { n }\end{array}$ & $\begin{array}{c}\text { Total } \\
\text { n }\end{array}$ \\
\hline Once daily/irregular & $8(30.8 \%)$ & $8(30.8 \%)$ & $10(38.5 \%)$ & $26(100 \%)$ \\
Twice daily/regular & $5(14.7 \%)$ & $7(20.6 \%)$ & $22(64.7 \%)$ & $34(100 \%)$ \\
Total & $13(21.7 \%)$ & $15(25 \%)$ & $32(53.3 \%)$ & $60(100 \%)$ \\
\hline
\end{tabular}

Values are given as median, TP1: At presentation; TP2: after 1 month of treatment, *The results of transfused patients $(\mathrm{n}=3)$ were excluded

\section{Statistical analysis}

Data were analyzed using SPSS for Windows v.11.0 (SPSS Inc., Chicago, IL. USA). The Mann Whitney U test was used for group comparisons. Differences in qualitative data were evaluated using the chi-square and Fischer exact tests. Correlations between variables were evaluated using Spearman's correlation coefficient.

\section{Results}

There wasn't a significant difference in tooth brushing habits $(p>0.05)$ or level of education between the 2 groups ( $>>0.05)$ (Table 2). Additionally, there wasn't a significant difference in OHI-S, DMFT index, or CPI scores between the groups ( $>00.05$ ) (Table 3). PD index and GBI scores were higher in the patient group than in the control group ( $\mathrm{p}<0.05)$ (Table 3 ), and CPI scores in the patient and control groups differed significantly $(\mathrm{p}<0.05)$-the patients had more sites with a PD $\geq 6 \mathrm{~mm}$ (CPI Score 4) and more patients bled during probing (CPI score 1) (Table 3). There was a significant correlation between PD index and GBI scores in the patient group $(\mathrm{p}<0.05)$, whereas mean PD index and GBI scores were significantly correlated with CPI score in both groups $(p<0.05)$ (Table 4).

\section{Discussion}

Undiagnosed hematologic disorders are an important health problem that dentists must be aware of. It was reported that some patients are diagnosed following oral symptoms and complications that occur during and after dental treatment [13-15,18]. Case reports have described submucosal hemorrhaging, gingival bleeding, petechiae, ecchymosis, and hematomas in patients with IDPF [15-21].

Tooth brushing habits are affected by age, gender, level of education level, parental level of education, and fear of bleeding. Koivusilta et al. [22] and
Table 3. Clinical Parameters

\begin{tabular}{lcc}
\hline Parameter & $\begin{array}{c}\text { Patients Group } \\
(\mathbf{n = 2 0})\end{array}$ & $\begin{array}{c}\text { Control Group } \\
(\mathbf{n}=\mathbf{4 0})\end{array}$ \\
\hline DMF-T index & $8.60 \pm 3.83$ & $8.33 \pm 5.36$ \\
PD index & $2.37 \pm 0.74$ & $1.96 \pm 0.46$ \\
OHI-S & $1.23 \pm 0.54$ & $1.67 \pm 0.48$ \\
CPI Score & & \\
Score 0 & $0 / 20(0 \%)$ & $1 / 40(2.5 \%)$ \\
Score 1 & $3 / 20(15 \%)$ & $1 / 40(2.5 \%)$ \\
Score 2 & $5 / 20(25 \%)$ & $22 / 40(55 \%)$ \\
Score 3 & $6 / 20(30 \%)$ & $11 / 40(27.5 \%)$ \\
Score 4 & $6 / 20(30 \%)$ & $5 / 40(12.5 \%)$ \\
\hline
\end{tabular}

$\mathrm{p}<0.05$ (two- tailed)

Honkala et al. [23] reported that tooth brushing habits improved as the level of education increased. Although not statistically significant, there was a positive correlation between tooth brushing habits and level of education in the present study's patient group.

DMFT index scores were reported to be lower in the children with hemophilia than the controls [24-25]. DMFT index scores were similar in MielnicBlaszcak et al.'s [26] 2 study groups. In the present study DMFT index scores did not differ between the patients and controls. Mielnic-Blaszcak et al. [26] evaluated bacterial dental plaque in children with congenital hemorrhagic diatheses and observed that the level of oral hygiene was lower in the patients than in the healthy children. In the present study the level of oral hygiene was similar in both groups.

Mean PD index and GBI scores were significantly correlated in the patient group and were higher than those in the control group. Moreover, more patients had CPI score 1 and score 4 than did controls. These findings indicate that gingival inflammation were more frequent and PD index scores were higher in the patients than the controls.

Periodontal health is important in patients with bleeding disorders because inflamed gingiva is at 
Table 4. Correlation Between CPI and PD İndex Scores, and Between PD İndex and GBI Scores

\begin{tabular}{|c|c|c|c|c|c|}
\hline & & \multicolumn{2}{|c|}{ Mean PD index } & \multicolumn{2}{|c|}{ CPI } \\
\hline & & $\mathbf{r}$ & $\mathbf{p}$ & $\mathbf{r}$ & $\mathbf{p}$ \\
\hline Patient group & Mean PD & - & - & 0.527 & 0.017 \\
\hline \multirow[t]{2}{*}{ Control group } & Mean PD & - & - & 0.469 & 0.002 \\
\hline & Mean GBI & 0.302 & 0.059 & 0.336 & 0.034 \\
\hline
\end{tabular}

Spearman's correlation analysis, $\mathrm{p}<0.05$ (two- tailed)

risk of bleeding. Good oral health reduced the incidence of unnecessary bleeding in patients with bleeding disorders [15]. In the present study the level of oral hygiene was similar in both groups. An interesting finding is that the patients had deeper pocket depth and higher levels of gingival inflammation than the controls. The present study's findings show that the incidence of periodontal inflammation was higher in the patients than in the healthy controls. The findings also show that both groups had poor oral hygiene; however, PD index and GBI scores were significantly higher in the study group than the control group. Our results supposed that IDPF affects periodontal tissues negatively. Alterations in platelet functions which result a with delayed or impaired wound healing may also contribute on these negative effects [27].

\section{Conclusion}

Regular oral-dental examination can play an important role in the diagnosis and screening of hematologic disorders. We think that patients with bleeding disorders should be examined regularly by dental specialists and that oral hygiene educational programming may benefit such patients. More comprehensive studies are needed in order to reach a more definite conclusion on the relation between periodontal health and IDPF. Determination of the effect of bacterial dental plaque on gingiva and oral wound healing (saliva, bacterial products, tissue interaction, etc.) in IDPF patients requires additional research.

\section{Acknowledgement}

This study was presented as a poster presentation at the IADR/CED \& ID Divisional Meeting in Thessaloniki Greece, 26-29 September 2007.

\section{Conflict of interest statement}

The authors of this paper have no conflicts of interest, including specific financial interests, relationships, and/or affiliations relevant to the subject matter or materials included.

\section{References}

1. George JN. Platelets. The Lancet 2000;355:1531-9. [CrossRef]

2. Ziv O, Ragni MV. Bleeding manifestations in males with von Willebrand disease. Haemophilia 2004;10:162-8. [CrossRef]

3. Quiroga T, Goycoolea M, Panes O, Aranda E, Martinez C, Belmont S, Munoz B, Zuniga P, Pereira J, Mezzano D. High prevalence of bleeders of unknown cause among patients with inherited mucocutaneous bleeding. A prospective study of 80 patients and 299 controls. Haematologica 2007;92:357-65. [CrossRef]

4. Toogeh G, Sharifian R, Lak M, Safaee R, Artoni A, Peyvandi F. Presentation and pattern of symptoms in 382 patients with Glanzmann Thrombasthenia in Iran. Am J Hematol 2004;77:198-9. [CrossRef]

5. Lak M, Peyvandi F, Mannucci PM. Clinical manifestations and complications of childbirth and replacement therapy in 385 Iranian patients with type 3 von Willebrand disease. Br J Haematol 2000;111:1236-9. [CrossRef]

6. Wray D, Dagg JH. Diseases of the Blood and Bloodforming Organs. In: Jones $\mathrm{JH}$, Mason DK eds Oral Manifestation of Systemic Disease. London: WB Saunders Company, 1980:262-96.

7. Catalano PM. Platelet and Vascular Disorders, In: Rose LF, Kaye D, eds. İnternal Medicine for Dentistry. St.Louis: Mosby Company, 1990:346-74.

8. Greene JC, Vermillion JR. The Simplified Oral Hygiene Index. J Am Dent Assoc 1964;68:7-13.

9. Greene JC. The Oral Hygiene Index--development and uses. J Periodontol 1967;38:625-37.

10. World Health Organization "Oral Health Surveys - Basic methods", 4th Ed. Geneva 1997:39-44. (published on the website http://www.whocollab.od.mah.se/expl/ orhsurvey97.html)

11. Ainamo J, Bay I. Problems and proposals for recording plaque and gingivitis. Int Dent J 1975;25:229-35.

12. World Health Organization "Oral Health Surveys - Basic methods", 4th Ed. Geneva 1997: 36 - 38. (published on 
the website http://www.whocollab.od.mah.se/expl/ orhcpitn97.html)

13. Gupta A, Epstein JB, Cabay RJ. Bleeding disorders of importance in dental care and related patient management. J Can Dent Assoc 2007;73:77-83.

14. Ghom AG. Textbook of Oral Medicine. New Delhi: Jaypee Brothers Medical Publisher, 2005.

15. Toygar HU, Guzeldemir E. Excessive gingival bleeding in two patients with Glanzmann thrombasthenia. J Periodontol 2007;78:1154-8. [CrossRef]

16. Songra AK, Darbar UR. Post-extraction bleeding--an aid to diagnosis? Case report. Aust Dent J 1998;43:242-3. [CrossRef]

17. Zakrzewska J. Gingival bleeding as a manifestation of von Willebrand's disease. A review of the literature and management. Br Dent J 1983;155:157-60. [CrossRef]

18. Keila S, Kaufman A, Itckowitch D. Uncontrolled bleeding during endodontic treatment as the first symptoms for diagnosing von Willebrand's disease. A case report. Oral Surg Oral Med Oral Pathol 1990;69:243-6. [CrossRef]

19. Fernandes Gomes M, De Melo RM, Plens G, Pontes EM, Silva MM, Da Rocha JC. Surgical and clinical management of a patient with Glanzmann thrombasthenia: a case report. Quintessence Int 2004;35:617-20.
20. Kantarci A, Cebeci I, Firatli E, Atamer T, Tuncer O. Periodontal management of Glanzmann's thrombasthenia: report of 3 cases. J Periodontol 1996;67:816-20.

21. Nixon KC, Keys DW, Brown G. Oral management of Glanzmann's thrombasthenia. A case report. J Periodontol 1975;46:364-7.

22. Koivusilta L, Honkala S, Honkala E, Rimpelä A. Toothbrushing as part of the adolescent lifestyle predicts education level. J Dent Res 2003;82:361-6. [CrossRef]

23. Honkala E, Rajala M, Rimpelä M. Oral hygiene habits among adolescents in Finland. Community Dent Oral Epidemiol 1981;9:61-8. [CrossRef]

24. Boyd D, Kinirons M. Dental caries experience of children with haemophilia in Northern Ireland. Int $\mathrm{J}$ Paediatr Dent 1997;7:149-53. [CrossRef]

25. Sonbol H, Pelargidou M, Lucas VS, Gelbier MJ, Mason C, Roberts GJ. Dental health indices and caries-related microflora in children with severe haemophilia. Haemophilia 2001;7:468-74. [CrossRef]

26. Mielnik-Blaszczak M. Evaluation of dentition status and oral hygiene in Polish children and adolescents with congenital haemorrhagic diatheses. Int J Paediatr Dent 1999;9:99-103. [CrossRef]

27. Klinger $\mathrm{MH}$. Inflammation. In: Michelson $\mathrm{AD}$ eds Platelet. Boston: Academic Press, 2002: 459-67. 